\title{
PREFACE TO THE 1959 EDITION
}

THE PAGES that follow reflect a direct concern with international relations and a long-standing interest in political theory. The latter dates from my years at Oberlin College where John and Ewart Lewis led me to feel the fascination of theory and to understand its importance in the study of politics. Later, at Columbia University, I was fortunate enough to be one of the students of the late Franz Neumann, whose brilliance and excellence as a teacher can never be forgotten by those who knew him.

My most immediate and my deepest debts are to William T. R. Fox. From the first vague outline of the manuscript to the final version here presented, he willingly gave his advice and perceptive criticisms. Moreover, as Director of Columbia University's Institute of War and Peace Studies, he made it possible for me to devote summers and parts of the academic year as well to research and writing. It is insufficient to say that because of him this is a better book, for without his encouragement and counsel it is difficult to see how there would be any book at all.

I have been unusually fortunate in my other critics as well: Herbert A. Deane and John B. Stewart, both of Columbia University, and Kenneth W. Thompson of the Rockefeller Foundation. Each was kind enough to read the entire manuscript at some stage of its preparation, and Professor Stewart patient enough to read it at two different stages. Each made suggestions that saved me from many errors and, more important, that caused me to reconsider and often to recast substantial parts of the manuscript, 
though I did not always come to conclusions they would accept.

My wife has done more than keep the children quiet and move commas around, more than criticize and read proof; she did most of the research for one chapter and contributed ideas and information to all of them. I should also like to thank the Columbia University Press for its understanding of the problems an inexperienced author must face and its generous assistance to him in overcoming them.

Excerpts from the works of others often conveyed the ideas I had in mind with more felicity than I could hope to achieve. I have therefore quoted freely and wish to thank the following publishers for their kind permission to quote from copyrighted works: George Allen and Unwin, Ltd., for John Hobson's Imperialism; Constable and Company, Ltd., for Jean Jacques Rousseau's A Lasting Peace through the Federation of Europe, translated by C. E. Vaughan; E. P. Dutton and Company, Inc., for Jean Jacques Rousseau's The Social Contract, translated by G. D. H. Cole (Everyman's Library edition); William Morrow and Company, Inc., for Margaret Mead's Coming of Age in Samoa (copyright I928 by William Morrow and Company) and And Keep Your Powder Dry (copyright 1942 by Margaret Mead); the Philosophical Library for Psychological Factors of Peace and War, edited by T. H. Pear; and the Social Science Research Council for Otto Klineberg's Tensions Affecting International Understanding.

Kenneth N. Waltz

Swarthmore College

April 1959 
MAN, THE STATE, AND WAR 
